\title{
Gry (dy)wersyfikacyjne, czyli o praktykowaniu poetyki w dydaktyce uniwersyteckiej
}

\section{(Di)versification games, i.e. on practicing poetics at the university level}

\author{
||Joanna Grądziel-Wójcik
}

\begin{abstract}
The article discusses poetics' significant place and role in the university literary didactics - it is a subject which introduces students into rudiments of literary theory and prepares them to practice the art of interpretation. The author focuses on the role of versification in philological education and underlines its structuralist tradition and tendency towards semantization and antropologization versificational devices. Researching verse enables desirable closeness of literature and theory which results in functionalizing versificational choices in concrete, historically and socially definite context - in this aspect versification becomes an object of modern humanistic thought. The author proclaims the necessity of enhancing the status of this problematics in academic training as well as its diversification through discussing versology also within historic-literary curricula.
\end{abstract}

Key words: versification, poetics, literary theory, interpretation.

Streszczenie: Artykuł omawia miejsce i zadania poetyki w uniwersyteckim kształceniu polonistycznym, która wprowadza studentów w podstawy teorii literatury oraz przygotowuje do praktykowania sztuki interpretacji. Szczególną uwagę autorka poświęca roli wersyfikacji w edukacji filologicznej, podkreślając jej strukturalistyczne tradycje oraz dążenie do semantyzacji i antropologizacji wersologicznych chwytów. Dzięki badaniom form wierszowych możliwe jest pożądane zbliżenie teorii do literatury, które pociąga za sobą sfunkcjonalizowanie wyborów wersyfikacyjnych w konkretnym, historycznie i społecznie określonym kontekście, tym samym włączając wersologię w przestrzeń współczesnej refleksji humanistycznej. Konieczne jest także dowartościowanie tej problematyki w kształceniu akademickim i jej dywersyfikacja poprzez przywoływanie również na przedmiotach historycznoliterackich.

Słowa kluczowe: wersyfikacja, poetyka, teoria literatury, interpretacja.

Przedmioty teoretycznoliterackie należą z pewnością do najtrudniejszych dla rozpoczynającego przygodę z polonistyką adepta pierwszego roku studiów, zwłaszcza licencjackich. Zwykle programy kształcenia przewidują kursy poetyki oraz analizy dzieł literackich, które wprowadzają w rudymenty teorii literatury i mają przygotowywać do praktykowania 
sztuki interpretacji. Mimo podstaw stylistyki i kompozycji, jakie wynoszą (czy też: powinni wynieść) ze szkół średnich ich absolwenci, generalnie większość omawianych zagadnień stanowi novum dla początkujących studentów, którzy niejednokrotnie po raz pierwszy poddają świadomej refleksji budowę tekstu lub ze zdziwieniem mierzą się z pytaniami podstawowymi - o status literatury i teorii oraz powiązanie tej ostatniej z praktyką. Takie warsztatowe wprowadzenie $\mathrm{w}$ tajniki interpretacji na początku literaturoznawczej drogi, orientujące w metodologicznych kontekstach i ustanawiające teoretyczny język opisu, wydaje się nie do przecenienia na wstępie uniwersyteckiej edukacji filologicznej. Właśnie w ramach poetyki możliwe jest rozbudzanie i rozwijanie umiejętności i wrażliwości interpretacyjnej, prezentowanie różnorodnych narzędzi przydatnych $\mathrm{w}$ pracy $\mathrm{z}$ tekstem z jednoczesną ich „instrukcją obsługi”, a co najważniejsze - uświadamianie metodologicznej interesowności stosowanych strategii lektury, uczulanie na jednostkowość, nieuniwersalność reguł wyprowadzanych z samych tekstów literackich, a wszystko to w celu maksymalnego wyzyskania potencjału teoretycznego w praktyce.

Po zakończonych ćwiczeniach z poetyki student powinien umieć zastosować wybrane przez siebie narzędzia teoretyczne, świadomie uruchamiając poznane metody analityczne i interpretacyjne, dopasowując je do konkretnego utworu i umieszczając w odpowiednich kontekstach historycznoliterackich, społeczno-kulturowych czy biograficznych, z wykorzystaniem odpowiedniej terminologii i literatury przedmiotu. Powinien nie tylko sprawnie analizować, interpretować i wartościować teksty, ale także rozumieć, w jaki sposób to robi i jakie konsekwencje dla końcowego efektu jego działań niesie wybrana przez niego metoda. Wśród podstawowych umiejętności absolwenta takiego kursu znajduje się analiza wersyfikacyjna utworu, jego warstwy stylistycznej i kompozycyjnej oraz rozpoznanie i charakterystyka najważniejszych gatunków literackich z uwzględnieniem, rzecz jasna, perspektywy poetyki historycznej. Przede wszystkim jednak student musi zmierzyć się z trudnym, nieoczywistym dla niego językiem teoretycznoliterackiej spekulacji, nauczyć się krytycznie czytać sformułowane w nim artykuły oraz samodzielnie wykorzystywać proponowane w nich pojęcia i strategie w konkretnych poetyckich zbliżeniach. Wart podkreślenia jest także praktyczny, stricte warsztatowy charakter tego typu zajęć, nastawionych na bliskie czytanie, mikroanalizy i semantyczne komplikacje, a tym samym odkrywających potencjał poetyki na podstawie rozbiorów pojedynczych przypadków literackich.

Tu szczególne znaczenie ma bowiem praktykowanie teorii, rozumiane za Ryszardem Nyczem jako zerwanie ze strukturalistycznym aplikowaniem pojęć teoretycznych (ale nie z rzetelnymi podstawami filologicznej analizy!): poetyka nie stanowi bowiem „zamkniętego systemu ogólnych twierdzeń o uniwersalnej naturze, cechach i funkcjach przedmiotu, którą by można aplikować w gotowej postaci do testowania właściwości literackich 
obiektów”, lecz staje się "słabą teorią małego czy średniego zasięgu” (Nycz 2012 , 14), a nawet - jeśli pójść dalej jeszcze - poetyką momentalną ${ }^{1}$, sprawdzającą się w odniesieniu do indywidualnych zdarzeń literackich i z nich wyprowadzającą swe formuły. Zajęcia z poetyki stają się w ten sposób znakomitą okazją na „praktykowanie teorii” właśnie (Nycz 2012, 14), wsłuchujące się $\mathrm{w}$ potrzeby tekstu i przywołujące bliskie mu konteksty historyczno-społeczne, kulturowe, cywilizacyjne, nieroszczące sobie zarazem prawa do uogólnień i uniwersalizacji. Na tym właśnie polega ta sztuka - na łączeniu jednostkowego, czułego na różnice i niepodobieństwa spojrzenia na literature $\mathrm{w}$ liczbie pojedynczej $\mathrm{z}$ ponadjednostkowymi, utrwalonymi $\mathrm{w}$ tradycji i zakorzenionymi metodologicznie procedurami interpretacyjnymi. Warto zatem na wstępie pobudzić studentów do myślenia, stawiając im teoretyczne, zmuszające do refleksji pytania: po co poetyka literaturze? do czego literatura potrzebna jest poetyce? Empiryczne nastawienie poetyki, jej pragmatyczność połączona z innowacyjnością i performatywnością rozwiązań, musi wysunąć się na plan pierwszy, wyrabiając u czytelników rozpoczynających swą literaturoznawczą profesję dobre (elastyczne, skuteczne) nawyki interpretacyjne. Poznając różnorodne modele i typologie, strategie, pojęcia czy chwyty przydatne w lekturze, powinni nauczyć się oni korzystać z ich repertuaru w niestandardowy, kreatywny sposób, z uwzględnieniem spersonalizowanej i lokalnej perspektywy, świadomi ograniczonej stosowalności danego narzędzia, sprawdzającego się zawsze tylko częściowo i sytuacyjnie. Nie ma metody doskonałej, lecz warto wiedzieć, spośród jakich możliwości możemy wybierać. Poetyka uniwersytecka powinna te obszary wskazywać i opisywać, ale nie normatywizować, tłumacząc potencjalne szyfry czy generatory sensu, ale też wyrabiając u młodych literaturoznawców odruch poszukiwania i kreowania nowych rozwiązań.

O ile stylistyka, kompozycja i genologia mają stałą i znaczącą pozycję w kształceniu akademickim, o tyle wersyfikacja, w moim przekonaniu, jest niekiedy traktowana po macoszemu, pozostając dwa kroki za pozostałymi działami poetyki. Deklarowana co prawda w treściach kształcenia, w rzeczywistości bywa spychana na dalszy plan, zaś przedstawiana przez pryzmat liczenia sylab i akcentów, postrzegana jest przez studentów jako nieatrakcyjna i mniej przydatna w lekturze tekstów. Relatywnie rzadko staje się głównym bohaterem książek literaturoznawczych, nieczęsto gości też w pracach interpretacyjnych - czasem świetne skądinąd odczytania poezji mówiącej wierszem w ogóle nie podejmują tropu wersyfikacyjnego, neutralnie traktując ten aspekt budowy tekstu. Nie znaczy to jednak, że w ostatnich dziesięcioleciach nie powstawały wartościowe, a zarazem atrakcyjne dydaktycznie prace, które eksplorując wersologiczną stronę tekstów, zachowały w polu widzenia całościową sferę sensów, nie izolując

\footnotetext{
${ }^{1}$ Nawiązuję tu do koncepcji „literaturoznawstwa momentalnego” Janusza Sławińskiego, stanowiącego „oddolny »kontrjęzyk " o minimalnym zasięgu stosowalności, który czyni wyłom w odgórnym języku interpretacji”, dostosowując aktualną metodę lektury do potrzeby tekstu i jego "chwili” (Sławiński 2006, 76).
} 
ich od kontekstów kulturowych. I choć studentom rzeczywiście trudno czyta się kompendia z lat 60. i 70., warto podsunąć im zarówno klasyczne opracowania Lucylli Pszczołowskiej, Marii Dłuskiej, Edwarda Balcerzana czy Wojciecha Kulawika, jak i późniejsze propozycje wersologicznych uporządkowań, zwłaszcza dotyczące wiersza wolnego - Doroty Urbańskiej, Adama Grabowskiego, Witolda Sadowskiego czy Pawła Bukowca². Dlatego obok podręcznikowych publikacji dających ogląd całości warto przypominać (wpisać do bibliografii przedmiotu i omawiać na zajęciach) także jednostkowe, autorskie, zorientowane na wersyfikację, ale poza nią wykraczające, projekty interpretacyjne, pokazujące na konkretnych przykładach semantyczny potencjał (nie tylko wierszowej) budowy. Wśród nich znajdują się zarówno prace teoretyczne $\mathrm{z}$ jednej strony formułujące pewne koncepcje wersologiczne, z drugiej zaś demonstrujące jednocześnie ich zastosowanie na danym materiale poetyckim, jak i interpretacje jednego wiersza, nakierowane czy szczególnie wrażliwe na wersyfikacyjną poszczególność, wyjątkowość tekstu. Wykorzystanie tego typu artykułów na zajęciach stanowiłoby doskonały przykład praktykowania wersyfikacji w służbie sztuki interpretacji. Pokażmy studentom, jak można czytać przez pryzmat wiersza poezje Czesława Miłosza (Kopczyńska 2002, Barańczak 1995, Balbus 1985), Wisławy Szymborskiej (Balcerzan 1997, Bukowiec 2015, Grądziel-Wójcik 2013), Zbigniewa Herberta (Dobrzyńska 2003, Mikołajczak 2004), Stanisława Barańczaka (Dembińska-Pawelec 2010) czy Juliana Tuwima (Opacki 2001, Bukowiec 2015) - można by zresztą długo wymieniać kolejne przykłady. To z konkretnych zbliżeń poezji Miłosza wyprowadzone zostały pomysły interpretacyjne „walki z wierszem” (Balbus 1985, $464)^{3}$, architektonicznego lub psychosomatycznego czytania tekstów późnego Mirona Białoszewskiego (Sadowski 1999, Grądziel-Wójcik 2011) lub odkrywania cielesno-metafizycznych znaczeń utworów Juliana Przybosia (Dziadek 2002) $^{4}$. Punktem dojścia w świetle poststrukturalistycznych przemian wersologii staje się zatem nie tylko semantyzacja wersologii, lecz także antropologizacja wersologicznych chwytów.

Od końca lat 60. w polskiej nauce o wierszu rozwijały się - obok prac komparatystycznych, porównujących systemy metryki słowiańskiej - badania semantyki form wierszowych, korzystające ze strukturalno-semiotycznego zaplecza, których znaczeniowy potencjał był podkreślany i analizowany w tekstach Teresy Dobrzyńskiej, Zdzisławy Kopczyńskiej, Marii Renaty Mayenowej, Lucylli Pszczołowskiej i Doroty Urbańskiej. Najważniejsze pytania dotyczyły funkcjonalizacji dokonywanych wyborów wersyfikacyjnych:

\footnotetext{
${ }^{2}$ Wybrane prace wymienionych autorów znajdują się w bibliografii.

${ }^{3}$ Sformułowanie to zaproponował Stanisław Balbus, a wykorzystał Stanisław Barańczak, interpretując rytmiczną organizację Świtów Czesława Miłosza: „Tocząca się tu w materii brzmieniowo-rytmicznej »walka z wierszem « jest zewnętrzną formą głębiej ukrytego buntu poety - zdefiniowanego jako ten, który pragnie »prawa zbadać« - przeciw koniecznościom egzystencji, przeciw jej nie uznającym sprzeciwu ograniczeniom, jej despotycznym rytmom i porządkom" (Barańczak 1995, 21-22).

${ }^{4}$ Zgodnie z zaproponowanym przez autora projektem krytyki somatycznej (Dziadek 2007).
} 
„W jaki sposób forma wierszowa nabiera charakteru znakowego? Co o tym decyduje?”, czytamy w klasycznym już tekście Pszczołowskiej sprzed ponad trzydziestu lat (Pszczołowska 2002, 270). Obecnie daje się zaobserwować dążenie do przełamania strukturalnej kategoryzacji wersologii, próbę włączania refleksji nad wierszem w relatywistyczne i konstruktywistyczne nurty metodologii, podkreślające przede wszystkim przygodność i lokalność wierszowej praktyki. Strukturalistyczna w swej źródłowej biografii wersyfikacja bardziej niż inne obszary poetyki opiera się zwrotom kulturowym, mając niewielkie szans na atrakcyjne drugie życie, jak na przykład syllepsa w tropologicznej koncepcji podmiotowości Ryszarda Nycza (Nycz 1997). A jednak drobiazgowe wiwisekcje wersologiczne dokonywane na tkance wiersza coraz częściej uruchamiają różnorodne strategie czytania, tak strukturalistyczne, hermeneutyczne, jak i pragmatystyczne, zabarwione somatopoetyką, zakładające bliskie czytanie i kulturowe otwarcie. Z jednej strony bowiem należy znać tradycję wierszowania, z drugiej warto pozwolić na swobodę interpretacyjną czytelnikowi, który rozpozna wiersz wtedy, gdy założy jego istnienie ${ }^{5}$. Uruchamia to pragmatystyczne podejście do wersyfikacji przy założeniu, że układ sylab i akcentów - owo współistnienie dwóch grających ze sobą porządków, wersowego i składniowego - to jeszcze jeden kod artystyczny, który powstaje w interpretacyjnej (re)konstrukcji. Przywołując eksperyment Fisha, nie możemy jednak zapominać o dochodzącym z głębi strukturalizmu echu Jakobsonowskiego twierdzenia, że wiersz zawsze implikuje funkcję poetycką (Jakobson 1989). Paweł Bukowiec tę złożoną sytuację wersyfikacji postrzega tak:

wiersz jest nie tyle obiektywnie istniejącym zjawiskiem (jak na przykład spadek temperatury), ile raczej opisem zaprogramowanego przez tekst (przez jego głosową aktualizację i/lub zapis graficzny) doznania (zimno), wynikiem interpretacji, której konwencje są w dodatku historycznie zmienne (mniej więcej tak, jak geograficznie czy wręcz osobniczo zmienne może być odczucie chłodu). Innymi słowy, żeby zaistniał wiersz, odbiorca (słuchacz lub czytelnik) musi go jako wiersz rozpoznać, musi dostrzec, że pauza tworzy szereg (Bukowiec 2015, 13-14).

Nawet w tak antyesencjalistycznej perspektywie, wpisującej się w nowy sposób myślenia, przydatna jest rzetelna filologiczna analiza, wdzierająca się w semantyczne zakamarki wersyfikacji. Warto zatem zabiegać, by kulturowa teoria literatury wchłonęła także sferę wyborów wersyfikacyjnych tekstów, nie tracąc stabilnego wersologicznego podłoża. Brak lub nadmiar jednej sylaby, zastosowanie toku przerzutniowego lub składniowego, przesunięcie akcentu, przełamanie metrum lub spotęgowanie rytmiczności wiersza dają się interpretować jedynie kontekstowo, zrelatywizowane wobec semantyki tekstu z jednej strony, z drugiej zaś zależne od pomysłowości czytelnika, którego ograniczają jedynie ramy dyktowane przez wybrany przezeń język teorii. To właśnie na terenie wiersza ma szansę uwidocznić się tak pożądane zbliżenie teorii do literatury, jej praktykowanie, które

\footnotetext{
${ }^{5}$ Nawiązuję tu do artykułu S. Fisha Jak rozpoznać wiersz, gdy się go widzi (Fish 2007).
} 
pociąga za sobą sfunkcjonalizowanie wyborów wersyfikacyjnych w konkretnym, historycznie i społecznie określonym kontekście, tym samym włączając wersologię w horyzont współczesnej refleksji humanistycznej.

Należy zatem - także w dydaktyce akademickiej - wyczytywać i wynajdywać w interpretacyjnych zbliżeniach ową antropologiczną wartość wynikająca z gier wersyfikacyjnych. Zwracać uwagę na tę różnicę, która wynika z obrania formy wierszowanej, a która jest zawsze znakiem lub śladem pewnego światopoglądu czy światoodczucia, "formą myślenia świata”, jakby powiedział Stanisław Balbus, gdyż pewne rzeczy „są dziś nie do pomyślenia prozą" (Balbus 1985, 463). Dlatego tak ważne jest, by prowadząc studenta przez meandry lektury, pomóc mu zrozumieć relacje między wierszem a prozą, poezją a prozą, a przede wszystkim - wierszem a poezją, a także nauczyć go rozpoznawać interpretacyjne i „życiowe” konsekwencje wyboru mowy wiązanej ${ }^{6}$.

Znakomitym materiałem na zajęcia teoretycznoliterackie, ale także m.in. literatury najnowszej, jest tomik wszystkowiersze Krystyny Miłobędzkiej, testujący granice wiersza i poetyckości. Znajdziemy w nim między innymi eksperymentalnymi tekstami nietypowy utwór, który pozwoli nam sproblematyzować relację między wierszowością i poetyckością:

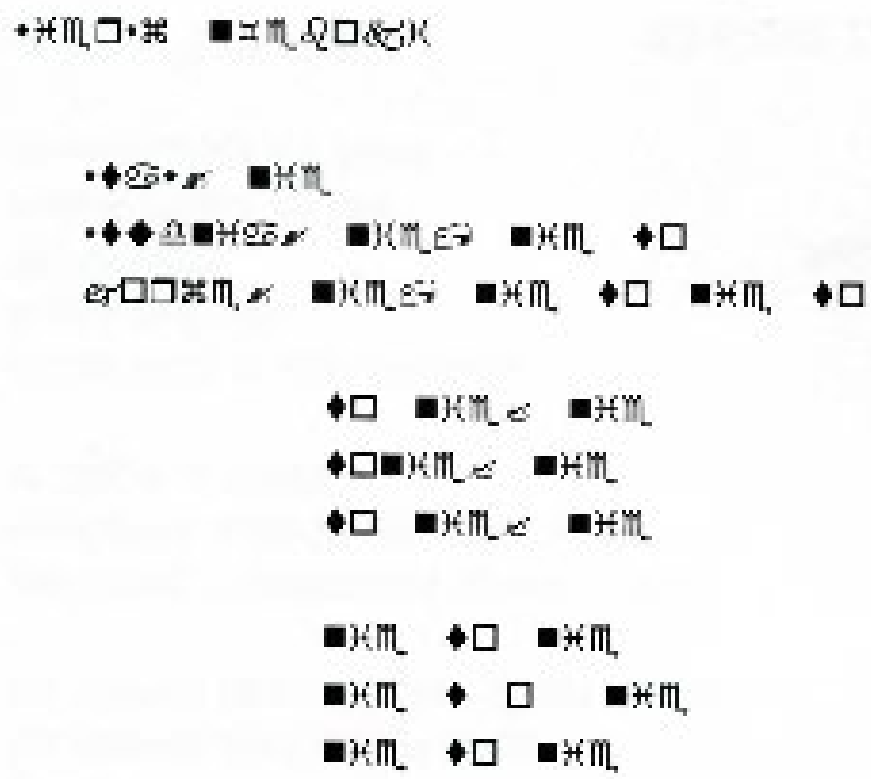

(Miłobędzka 2006, 259)

Warto pokazywać, że nawet jeśli „poezja nie zawsze / przybiera formę / wiersza", jak pisał Tadeusz Różewicz, to jednak najczęściej z jego potencjału korzysta, grając czy nawet negując wersyfikacyjne ramy. Uwrażliwiając studenta na relacje między porządkiem struktury metrycznej a sferą

${ }^{6}$ Można to na przykład sugestywnie pokazać, poddając interpretacji dwa różne zapisy - prozą i wierszem - tego samego utworu Bogusławy Latawiec, Ciemnie prywatne. W tomie Razem tu koncertujemy znajdziemy jego wersję prozatorską, zaś w późniejszych Odkrytkach - wierszowaną (Latawiec 1999, 28; Latawiec 2007, 37). 
semantyczną, prowokujemy go do stawiania pytań interpretacyjnych: co zadecydowało o takiej a nie innej budowie wersów? Jakie znaczenia mogą kreować decyzje wersyfikacyjne? Dlaczego wiersz wolny cytuje dawne systemy? Ale także: co na temat kondycji psychosomatycznej podmiotu mówi nam układ wersyfikacyjny? Jaka wizja świata wyłania się z niedokończonych, nieregularnych wersów? Jaki nastrój czy nastawienie „ja” kryje się w monotonnym rytmie amfibracha czy rytmicznym kroku jamba? Najtrudniejsze, ale i najciekawsze okazuje się wskazanie owego związku następstwa sylab akcentowanych i nieakcentowanych ze sposobem myślenia, postrzegania czy emocji podmiotu, interpretacyjne przełożenie zachwiania rytmu na ideologiczny sprzeciw, społeczne zaangażowanie, psychiczny wstrząs czy somatyczne przeżycie... Istotne jest nie tylko wskazanie stałych odniesień czy relacji między formą wiersza a tematem, choć utrwalone w tradycji stylistyczne walory form wierszowych należą do obowiązkowej wiedzy o wierszu, lecz także jednostkowe, sytuacyjne, indywidualne wykorzystanie czy wykreowanie semantyki wersyfikacji, za którą kryje się osobowy, zanurzony $\mathrm{w}$ życiu i doświadczeniu podmiot. Forma wierszowa, by stać się znakiem, nie musi bowiem nawiązywać jedynie do utrwalonych znaczeń (Pszczołowska 2002, 281). Nie o samą identyfikację chwytu w umiejętnościach wersyfikacyjnych tu chodzi - choć oczywiście od tego należy zacząć, ucząc rozpoznawania zabiegów wersyfikacyjnych, rozróżniania ich systemów i stylistycznych uwarunkowań - ale o swego rodzaju powiązanie wierszowych wyborów na wykreowane/ujawniające się doświadczenie podmiotu, słowem: o „metryczne znaki ANTROPOLO”.

Jeśli więc chcemy, by nasi absolwenci korzystali z pełnej gamy interpretacyjnych możliwości, powinniśmy starać się wykształcić wrażliwego na kulturowe i antropologiczne konteksty czytelnika, który nie poprzestanie na filologicznej analizie powtarzalności akcentów, sylab i zestrojów. Dlatego w dydaktyce polonistycznej warto kształcić umiejętności wersyfikacji nie tylko na poetyce, ale też powracać do tej tematyki na innych przedmiotach literaturoznawczych, by uniknąć wtórnej neutralizacji tej sfery znaczeniowej tekstu. Studenci, wybierając tematy prac dyplomowych z zakresu poezji, którzy po pierwszym roku stracili jakikolwiek kontakt z wersyfikacją, zmuszeni zostają często do odpominania i uzupełniania dawno zdobytej wiedzy i umiejętności. Poetyka to bowiem pierwszy, ale przecież nie ostatni moment, by zaszczepić przyszłym badaczom literatury i autorom prac interpretacyjnych uważność i czułość na metrum, brakujące sylaby i przełamania rytmu, wersyfikacyjne dialogi i szyfry. Należałoby zatem zmienić podejście do wersyfikacji, dokonując swoistej dywersyfikacji tej problematyki w kształceniu akademickim przez przywoływanie jej - kontekstowo, okazjonalnie - także na przedmiotach historycznoliterackich lub

\footnotetext{
${ }^{7}$ Metryczne znaki IDEOLO to tytuł rozdziału książki Pawła Bukowca, który poświęcony został wersyfikacyjnej interpretacji Balu w Operze Tuwima, nawiązując jednocześnie do słynnego fragmentu poematu. Badacz podkreśla, że za metrycznymi znakami poematu kryje się rzeczywistość, reprezentująca określony światopogląd ideologiczny (Bukowiec 2015, 97).
} 
przy okazji interpretacji najnowszych tekstów poetyckich, wszystko po to, by maksymalnie wykorzystać potencjał semantyczny tekstu (i czytelnika). Dążyć trzeba zatem do rozszerzenia i rozproszenia wersologicznej wiedzy i umiejętności na innych, niezależnych od poetyki kursach, a także różnicowania i urozmaicania interpretacji o ten aspekt analizy tekstu. Nic nie stoi na przeszkodzie, by wskazywać na wersyfikacyjne rozwiązania zarówno w sylabicznych tekstach Jana Kochanowskiego i sylabotonicznych propozycjach Adama Mickiewicza, jak i awangardowym wierszu Józefa Czechowicza, śledzić toniczne zabarwienia liryki Kazimiery Iłłakowiczówny, nieregularne gry z sylabikiem Marii Pawlikowskiej-Jasnorzewskiej czy wybijane jambem koncepty Zbigniewa Herberta.

Uczmy zatem całościowego spojrzenia na budowę tekstu, szczególnie uczulając na kształt wersyfikacyjny utworów, komplikujący czy przewartościowujący sferę ich sensów. W wierszowym zapisie może wszak kryć się ironia, zaprzeczenie, polemika z treściami wyrażonymi bezpośrednio w tekście - bywa, że wersyfikacyjne signifiant mówi w tekście co innego, niż signifié. Na takimż koncepcie, indywidualnym pomyśle, organizującym kształt graficzny wiersza opartych jest wiele współczesnych wypowiedzi poetyckich. Warto podkreślać ikoniczną funkcję wersyfikacji, która odwzorowuje zjawiska pozajęzykowe dzięki semantycznemu tematowi, nakłaniającemu do danej ścieżki lektury: „Ta sama struktura rytmiczna może imitować tak różne rzeczy, jak padanie deszczu, śniegu, jazdę konną czy taniec itp." (Dobrzyńska 2015, 229). Mniej oczywiste przypadki dotyczą semantyzacji struktury wersyfikacyjnej. Miłobędzka konstruuje WIERSZ-ŚLIMAK, który:

zostawia

po sobie

srebrną ścieżeczkę

(Miłobędzka 2006, 264)

Inaczej rzecz rozgrywa Wisława Szymborska w Akrobacie, w rozkołysanej składni wiersza, rozpiętej na klauzuli i nagłosie, odwzorowując ruch cyrkowca chwiejącego się na trapezie:

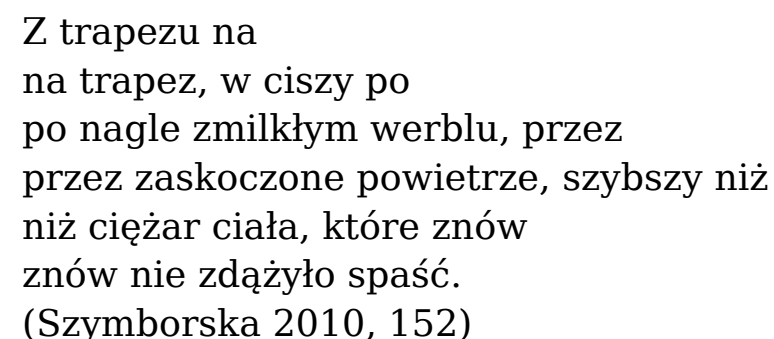

Ikoniczną grę wersyfikacyjną prowadzi również Miron Białoszewski, w którego wierszu z tomu Odczepić się, pisanym po przeprowadzce na dziewiąte piętro wieżowca, pręty balkonu czy rusztowań zasłaniają podmiotowi krajobraz: 
Wyglądanie

przez pręty

ebo

ężyc

(Białoszewski 1994, 85)

Szczególnie ciekawe są zwłaszcza te sytuacje, gdy wiersz staje się „,sygnaturą autorską - znakiem indeksalnym wskazującym na autora" (Dobrzyńska 2015, 236). Z konstrukcji wierszowej przebija wówczas kondycja psychosomatyczna „ja”, jak w wypowiadanych nerwowo ,jednym tchem”, „jąkających się" wierszach Stanisława Barańczaka, których podmiot czuje się osaczony i dusi się w zideologizowanym, nieprzyjaznym mu świecie, czy wspomnianych już wierszach Białoszewskiego, uwidaczniających sytuację sylleptycznie i psychocieleśnie rozumianego podmiotu w nowej blokowej rzeczywistości. Na jedenastym piętrze oddaje rytm przemieszczającego się „ja”, narzucając odbiorcy perspektywę idącego:

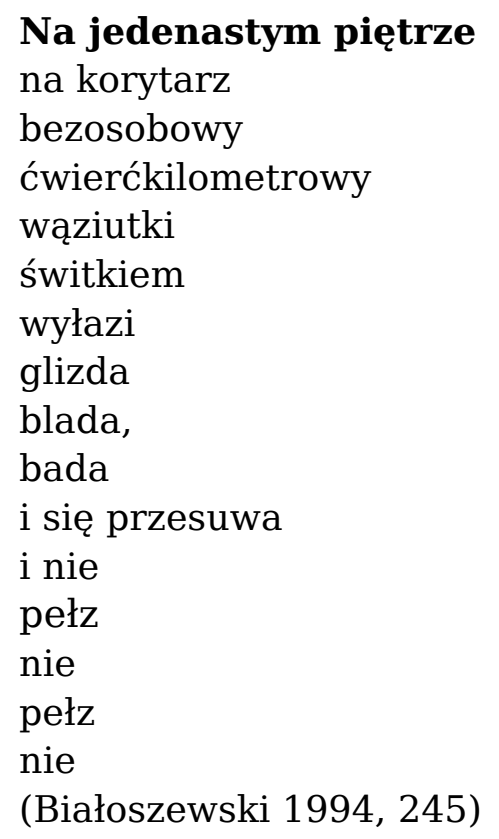

Takie nieoczywiste, dydaktycznie nośne przykłady semantycznej i antropologicznej aktywizacji wiersza, osadzające go w kontekstach autobiograficznych, społecznych, historycznych czy kulturowych, można by mnożyć. Niezauważanie decyzji wersyfikacyjnych (bez względu na to, czy są one świadome i zamierzone), zubaża nasze odczytanie, pozbawia poezję przybierającą formę wiersza głosu ważnego, choć jedynie implikowanego, zwykle wyciszonego i głęboko ukrytego. Absolwent polonistyki powinien umieć go wysłyszeć, by odczytać semantykę mowy wiązanej, która stanowi integralny znak poetyckości i otwiera na ogrom znaczeń, zależnych od kompetencji i wyobraźni interpretatora. Powinien umieć zauważyć i wynaleźć problem wersyfikacyjny - wszystko po to, by wydobyć jego antropologiczny sens, by móc powiedzieć jak najwięcej o wyłaniającym się z tekstu doświadczeniu podmiotu. Liczenie sylab i akcentów nie jest bowiem nudną zabawą 
wersologów, dla których „obojętna jest zawartość poetycka wierszowanej mowy” (Przyboś 1959, 232), lecz wersyfikacyjna grą o znaczenia, gdziekolwiek je lokujemy.

\section{Bibliografia:}

Balbus Stanisław, 1985, „Pierwszy ruch jest śpiewanie”. (O wierszu Miłosza rozpoznanie wstępne), w: Poznawanie Miłosza. Studia i szkice o twórczości poety, Kwiatkowski J. (red.), Kraków.

Balcerzan Edward, 1997, Rosyjskie Urodziny Wisławy Szymborskiej, w: Śmiech pokoleń - płacz pokoleń, Kraków.

Barańczak Stanisław, 1995, Tunel i lustro. Czesław Miłosz: „Świty”, w: Pomyślane przepaście. Osiem interpretacji, Opacki I. (posłowie), Katowice.

Białoszewski Miron, 1994, „Odczepić się” i inne wiersze opublikowane $w$ latach 1976-1980, Warszawa.

Bukowiec Paweł, 2015, Metronom. O jednostkowości poezji „nazbyt” rytmicznej, Kraków.

Chrząstowska Bożena, Wysłouch Seweryna, 1978, Poetyka stosowana, Warszawa.

Ćwiczenia z poetyki, 2006, Gajewska A., Mizerkiewicz T. (red.), Warszawa.

Dembińska-Pawelec Joanna, 2010, „Poezja jest sztuka rytmu”. O świadomości rytmu w poezji polskiej dwudziestego wieku (Miłosz - Rymkiewicz - Barańczak), Katowice.

Dłuska Maria, 1962, Próba teorii wiersza polskiego, Warszawa.

Dobrzyńska Teresa, 2015, Formy wiersza jako nośniki znaczeń, w: Tekst poetycki i jego konteksty. Zbiór studiów, Warszawa.

Dziadek Adam, 2002, O Notre-Dame raz jeszcze, w: Stulecie Przybosia, Balcerzan E., Balbus S. (red.), Poznań.

Dziadek Adam, 2007, Soma i sema - zarys krytyki somatycznej, w: Literackie reprezentacje doświadczenia, Bolecki W., Nawrocka E. (red.), Warszawa.

Fish Stanley, 2007, Jak rozpoznać wiersz, gdy się go widzi, w: Interpretacja, retoryka, polityka, Szahaj A. (red.), Kraków.

Grądziel-Wójcik Joanna, 2011, „Blok, ja w nim”. Doświadczenie architektury a rewolucja formy w późnej poezji Mirona Białoszewskiego, w: W kręgu literatury i języka. Analizy i interpretacje, Michalska-Suchanek M. (red.), Gliwice.

Grądziel-Wójcik Joanna, 2013, „Zachwiany rytm” wierszy Wisławy Szymborskiej, w: Potencjał wiersza, Sadowski W. (red.), Warszawa.

Jakobson Roman, 1989, Poetyka w świetle językoznawstwa, w: W poszukiwaniu istoty języka, t. 2, Mayenowa M.R. (wybór, wstęp i oprac.), Warszawa.

Kopczyńska Zdzisława, Dobrzyńska Teresa, Pszczołowska Lucylla, 2007, Znaczenie wyboru wiersza. Trzy studia, Warszawa.

Korwin-Piotrowska Dorota, 2011, Poetyka. Przewodnik po świecie tekstów, Kraków.

Kulawik Adam, 1990, Poetyka. Wstęp do teorii dzieła literackiego, Kraków.

Latawiec Bogusława, 2007, Odkrytki, Warszawa. 
Latawiec Bogusława, 1999, Razem tu koncertujemy, Poznań.

Mikołajczak Małgorzata, 2004, W cieniu heksametru. Interpretacje wierszy Zbigniewa Herberta, Zielona Góra.

Miłobędzka Krystyna, 2006, Zbierane 1960-2005, Wrocław.

Nycz Ryszard, 2012, KTL - wyjaśnienia i propozycje, w: Kulturowa teoria literatury 2. Poetyki, problematyki, interpretacje, Walas T., Nycz R. (red.), Kraków.

Nycz Ryszard, 1997, Tropy „ja”. Koncepcje podmiotowości w polskiej ostatniego stulecia, w: Język modernizmu. Prolegomena historycznoliterackie, Wrocław.

Okopień-Sławińska Aleksandra, 1965, Wiersz awangardowy dwudziestolecia międzywojennego, „Pamiętnik Literacki”, z. 2.

Opacki Ireneusz, 2001, Julian Tuwim, „Zadymka”, w: Liryka polska. Interpretacje, Prokop J., Sławiński J. (red.), Kraków.

Potencjał wiersza, 2013, Sadowski W. (red.), Warszawa.

Potkański Jan, 2004, Sens nowoczesnego wiersza: wersyfikacja Białoszewskiego, Przybosia, Miłosza i Herberta, Warszawa.

Pszczołowska Lucylla, 2003, Dlaczego wierszem, Warszawa.

Pszczołowska Lucylla, 1976, Forma wierszowa a utwór liryczny, w: Problemy teorii literatury, Seria 2, Markiewicz H. (red.), Wrocław.

Pszczołowska Lucylla, 2002, Semantyka form wierszowych, w: Wiersz - styl poetyka. Studia wybrane, Kraków.

Pszczołowska Lucylla, 1997, Wiersz polski. Zarys historyczny, Wrocław.

Przyboś Julian, 1959, O wersologii, w: Linia i gwar, t. II, Kraków.

Sadowski Witold, 1999, Tekst graficzny Białoszewskiego, Warszawa.

Sadowski Witold, 1987, Wiersz wolny jako tekst graficzny, Kraków.

Sławiński Janusz, 2006, Miejsce interpretacji, Warszawa.

Szymborska Wisława, 2010, Wiersze wybrane, wybór i układ Autorki, wydanie nowe, uzupełnione, Kraków.

Urbańska Dorota, 1995, Wiersz wolny. Próba charakterystyki systemowej, Warszawa.

\section{O Autorce:}

Joanna Grądziel-Wójcik - literaturoznawczyni, pracuje w Zakładzie Literatury XX wieku, Teorii Literatury i Sztuki Przekładu Instytutu Filologii Polskiej UAM. Zajmuje się historią literatury i sztuką interpretacji, przede wszystkim polską poezją XX i XXI w., ostatnio zaś zwłaszcza poezją kobiet. Autorka książek Poezja jako teoria poezji. Na podstawie twórczości Witolda Wirpszy (Poznań 2001), Przestrzeń porównań. Szkice o polskiej poezji współczesnej (Poznań 2010), „Drugie oko” Tadeusza Peipera. Projekt poezji nowoczesnej (Poznań 2010), Zmysł formy. Sytuacje, przypadki, interpretacje polskiej poezji XX wieku (Kraków 2016), Przymiarki do istnienia. Wątki i tematy poezji kobiet XX i XXI wieku (Poznań 2016, w druku). 
